\title{
A STUDY OF THE REFLEX MECHANISM OF SWEATING IN THE HUMAN BEING; EFFECT OF ANESTHESIA AND SYMPATHECTOMY
}

\author{
By RAMSDELL GURNEY AND IVAN L. BUNNELL \\ (From the Department of Physiology, University of Buffalo Medical School, Buffalo)
}

(Received for publication November 12, 1941)

Many investigations have been carried out in an effort to determine the purpose and mechanism of sweating. Such important contributions as the separation of insensible from sensible perspiration, the part that evaporation from the skin plays in temperature control of the body (1), the demonstration of the "emotional" sweating of the palms, soles and axillae (2), and the absorption of ultraviolet radiation by sweat (3) have done much to explain the purposes of this important physiological function. However, the actual mechanism of sweating is still far from clear. It is generally accepted that the sweat glands are innervated by the sympathetic nervous system but their response to parasympathetic stimulants and depressants only is difficult to understand (4). In addition, it is uncertain whether the general sweat secretion which follows exposure to high environmental temperature is a reflex phenomenon resulting from stimulation of heat receptors in the skin, or from the effect of warmed blood bathing the heat center in the brain, or from both. Kuno (5), for example, concludes that sweating is a pure reflex phenomenon except when the temperature is extreme. Martin (6), on the other hand, concludes that the most effective stimulus for sweating is a "rise in the temperature of the blood supply to the brain." Best and Taylor (7) state that "the usual stimulus to sweat secretion is a rise in blood temperature which exerts its effect in two ways-directly upon the nervous centers, which is of more importance, and reflexly by stimulation of heat receptors in the skin." That sweating can occur by central stimulation has been well shown $(8,9)$.

Much of the work on which these conceptions were based was done on animals, and quantitative estimations were frequently omitted; consequently, it appeared that certain aspects of this problem might be more adequately studied on human beings. If various parts of the sweating mechanism could be investigated separately, namely the sweat glands themselves, the motor sympathetic fibers and the sensory temperature fibers, it might be possible to determine whether the nervous reflex arc in whole or in part is essential for sweating in the human being.

\section{METHOD AND APPARATUS}

Of the various ways available for indicating qualitative activity of the sweat glands, a modification of the silver nitrate method was found most useful for our purposes (10). This test depends on the reduction of silver chloride by ultraviolet light. The area chosen for examination was carefully cleaned by soap, water, and alcohol. A white paper was then firmly pressed against this region for one minute. The paper was then removed, and ten per cent silver nitrate floated over it. After exposure to the sun or an ultraviolet lamp, if the sweat glands were active, small brown dots of reduced silver nitrate appeared on the paper which varied in number and intensity depending on the degree of sweat-gland activity. If the glands were inactive, no dots appeared.

The quantitative estimation of both sensible and insensible perspiration was determined as follows: Room air was sucked through a bottle of sulphuric acid and two large bottles of calcium chloride, by means of a water aspirator. Several preliminary tests indicated that the room air was in this way freed of moisture. The air then passed through an inverted glass cup with two side arms which was snugly applied and sealed by vacuum wax to the skin area to be tested. One side arm of the cup was attached by tubing to a weighed U-tube filled with fresh calcium chloride. Any increase in weight of this U-tube was a result of moisture added to the air from the surface of skin under the cup. The degree of negative pressure was determined by a mercury manometer which likewise checked the air-tightness of the apparatus. The negative pressure at times caused some discomfort to the subject, but checks against a positive pressure system showed that no excess water vapor was obtained in this way. The air flow was controlled and determined by a gasometer and the most satisfactory rate was found to be between 3 and 5 liters per minute.

In each experiment dry air was run through the apparatus for some time to insure the elimination of any retained moisture. The forehead and arm were chosen as the most desirable sites for the quantitative measurements as sweat glands are abundant in these regions and 
no emotional sweating occurs in them except when psychic stimulation is very marked (11). The experiments were divided into exact ten-minute periods, and the U-tube was weighed and changed at the end of each of these. Control periods always preceded the heating periods. The presence or absence of sweat gland activity before the heat periods was confirmed by the silver nitrate test.

In those experiments in which heat was applied to an extremity, a radiant heater was used. This heater consists of a cage, open at both ends, containing a battery of eight electric light bulbs. The extremity to be tested was inserted into one of the open ends and radiation to other parts of the body surface was prevented by a blanket. By varying the number of lighted bulbs the temperature was maintained at approximately $48^{\circ} \mathrm{C}$.

(1) Normal sweat response to dry heat applied to an extremity. The first group of experiments was performed on healthy males in order to determine the quantitative output of moisture on some remote region (forehead or opposite extremity) during exposure of an upper extremity to dry heat. These experiments served as a control. Seven tests were performed, three of which are reported in Table $I$. As can readily be seen, a general pattern is evident in all individuals studied, although the total quantitative output of moisture from similar areas on the forehead of different individuals varies. Likewise the onset of sweating after exposure to heat is more rapid in some individuals than in others (J. B. and R. J.). Undoubtedly the humidity, environmental temperature, and individual characteristics play a part in these variations. But for one exception (I. B.) the sweat glands as indicated by the silver nitrate test were not secreting prior to the application of heat with the individual at rest. In summary, then, it may be said that on the application of heat to one arm the sweat glands on the forehead or opposite arm become active immediately or after a latent period (R. J.) and a progressive increase in output of moisture from the region studied follows.

(2) Histological study of the sweat glands in a sympathectomized area. Before the reflex mechanism of sweating can be studied, the condition of the glands themselves after separation from their motor nerve supply must be determined. Severing the sympathetic nerve supply to an extremity is a common surgical procedure. If denervation is complete, diminution or absence of sweat gland activity in the sympathectomized region occurs.
TABLE I

\section{Normal response}

J.B., Male, August 4, 1941. Cup on forehead. Room temperature $26.9-27.7^{\circ} \mathrm{C}$

\begin{tabular}{|c|c|c|c|c|c|}
\hline \multicolumn{3}{|c|}{ Heat left arm } & \multicolumn{3}{|c|}{ Heat right arm } \\
\hline Period & $\begin{array}{l}\text { Perspi- } \\
\text { ration }\end{array}$ & $\begin{array}{c}\text { Silver } \\
\text { nitrate } \\
\text { test } \\
\text { (Fore- } \\
\text { head) }\end{array}$ & Period & $\begin{array}{l}\text { Perspi- } \\
\text { ration }\end{array}$ & $\begin{array}{l}\text { Silver } \\
\text { nitrate } \\
\text { test } \\
\text { (Fore- } \\
\text { head) }\end{array}$ \\
\hline & $\begin{array}{l}\text { grams per } \\
120 \text { sq. mm. } \\
\text { per } 10 \\
\text { minutes }\end{array}$ & & & $\begin{array}{c}\text { grams per } \\
120 \text { sq. mm. } \\
\text { per } 10 \\
\text { minutes }\end{array}$ & \\
\hline $\begin{array}{c}\text { 18t Controi } \\
\text { 2nd Control } \\
L=1 \\
L=2 \\
L=3 \\
L=4\end{array}$ & $\begin{array}{l}0.0237 \\
0.0231 \\
0.0338 \\
0.0432 \\
0.0436 \\
0.0532\end{array}$ & $\begin{array}{r}\overline{+} \\
+ \\
+\stackrel{+}{+} \\
++++\end{array}$ & $\begin{array}{c}\text { 1st Control } \\
\text { 2nd Control } \\
R=1 \\
R=2 \\
R=3 \\
R=4\end{array}$ & $\begin{array}{l}0.0220 \\
0.0227 \\
0.0270 \\
0.0342 \\
0.0288 \\
0.0406\end{array}$ & $\begin{array}{r}\bar{z} \\
+ \\
++ \\
++ \\
++\end{array}$ \\
\hline
\end{tabular}

I.B., Male, July 23, 1941. Cup on forehead. Room temperature 27.7-28.5 $\mathrm{C}$.

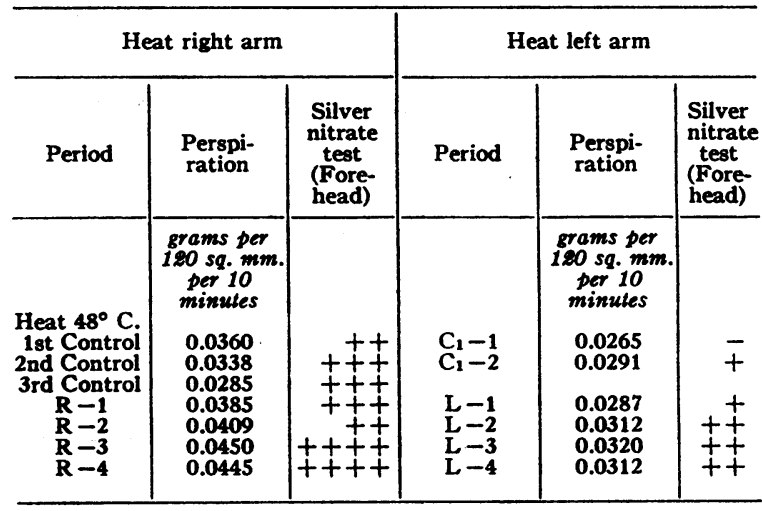
R.J., Male, July 14, 1941. Cup on forehead. Room temperature $_{25.8}$ C.

\begin{tabular}{|c|c|c|c|c|c|}
\hline \multicolumn{3}{|c|}{ Heat left arm } & \multicolumn{3}{|c|}{ Heat right arm } \\
\hline Period & $\begin{array}{l}\text { Perspi- } \\
\text { ration }\end{array}$ & $\begin{array}{c}\text { Silver } \\
\text { nitrate } \\
\text { test } \\
\text { (Fore- } \\
\text { head) }\end{array}$ & Period & $\begin{array}{l}\text { Perspi- } \\
\text { ration }\end{array}$ & $\begin{array}{l}\text { Silver } \\
\text { nitrate } \\
\text { test } \\
\text { (Fore- } \\
\text { head) }\end{array}$ \\
\hline $\begin{array}{c}\text { Heat } 48^{\circ} \mathrm{C} \text {. } \\
\mathrm{C}=1 \\
\mathrm{C}=2 \\
\mathrm{~L}=1 \\
\mathrm{~L}=2 \\
\mathrm{~L}=3 \\
\mathrm{~L}=4\end{array}$ & $\begin{array}{c}\text { grams per } \\
\text { 190 sq. mm. } \\
\text { per } 10 \\
\text { minutes } \\
0.0130 \\
0.0125 \\
0.0153 \\
0.0145 \\
0.0208 \\
0.0223\end{array}$ & $\begin{array}{r}\bar{t} \\
++\bar{t}\end{array}$ & $\begin{array}{l}C_{1}-1 \\
C_{1}=2 \\
R=1 \\
R=2 \\
R=3 \\
R=4\end{array}$ & \begin{tabular}{|c|} 
grams per \\
120 sq. mm. \\
per 10 \\
minutes \\
0.0132 \\
0.0110 \\
0.0132 \\
0.0137 \\
0.0140 \\
0.0210
\end{tabular} & $\begin{array}{r}\bar{z} \\
\pm \\
++ \\
+++\end{array}$ \\
\hline
\end{tabular}

This surgical procedure prevents motor impulses from reaching the sweat glands; that is, it removes the motor side of the reflex arc. The question to be determined is whether the anhydrosis results from removal of the motor fibers to the sweat glands or whether it results from some change in the sweat glands themselves. Biopsy of the skin 
in regions to which the sympathetic nerves had been severed failed to show any alteration in the appearance of the glands, as compared to the appearance of the glands in normal regions to which the sympathetic nerve supply was intact. ${ }^{1}$

(3) Direct stimulation of sweat glands in sympathectomized area by mecholyl. A response of denervated sweat glands to a sudorific drug would be further proof of their integrity. Two women with Raynaud's disease were studied - one with a cervical sympathectomy and the other (M. H.) with a cervical and lumbar sympathectomy. In the former, both sympathetic chains had been cut below the 3rd dorsal ganglion and the 2nd and 3rd intercostal nerves had been severed just proximal to their union to form the nerve trunks. In the second patient (M. H.) a similar operative procedure was performed in the dorsal region and, in addition, the 2 nd and 3rd lumbar ganglia had been resected bilaterally. This resulted in a quadrilateral sympathectomy in the second case. The first patient had an absence of noticeable sweating on the face and upper extremities and the second, on the face and all four extremities. Intracutaneous injection in the sympathectomized arms of $0.1 \mathrm{cc}$. of mecholyl in various dilutions, containing as little as 25 micrograms per cc. of the drug, invariably resulted in activity of the sweat glands in the injected area as indicated by the silver nitrate test. Injection of $0.1 \mathrm{cc}$. of sterile water as a control solution resulted in no activity of the sweat glands. In one instance the test was done ten days and in the other one year after operation. Judging from the number and size of the dots obtained by the silver nitrate test, the response to mecholyl was slightly less vigorous in the patient studied one year after denervation.

(4) Direct stimulation of sweat glands in sympathectomized area by heat. Procedures 2 and 3 above demonstrated that sweat glands deprived of their sympathetic nerve supply appeared normal histologically and could respond to intracutaneous injections of mecholyl. It was therefore of interest to determine whether denervated sweat glands could respond to the local application of heat. Hot pads applied to the sympathectomized

\footnotetext{
1 We wish to thank Dr. Kornel Terplan, Professor of Pathology, University of Buffalo, for securing and examining these specimens for us.
}

extremities in patient M. H., with cervical and lumbar sympathectomy, resulted in activity of the sweat glands in these areas as indicated by the silver nitrate test. No rise in the rectal temperature resulted from this procedure. A similar response can be seen in the second experiment (Table II): the sweat glands became active on the heated arm in the third heat period in spite of the fact that the sympathetic nerves were severed to this extremity. No activity of the sweat glands on the unheated right arm could be detected.

(5) An attempt to stimulate the sweat glands in a sympathectomized area remote from heated region. Procedures 2, 3 and 4 indicated that the sweat glands separated from their sympathetic nerves not only appeared normal histologically, but still responded to intracutaneous injections of a sudorific drug (mecholyl) and the local application of dry heat. The next question to be determined was whether these denervated glands could

\section{TABLE II}

Case with cervical and lumbar sympathectomy M.H., Female, July 31, 1941. Cup on forehead. Heat. applied to right arm. Room temperature $26.6-26.7^{\circ} \mathrm{C}$.

\begin{tabular}{c|c|c}
\hline \hline Period & Perspiration & $\begin{array}{c}\text { Silver nitrate test } \\
\text { (Forehead) }\end{array}$ \\
\hline & $\begin{array}{c}\text { grams per 180 } \\
\text { sq. mm. per 10 } \\
\text { minutes }\end{array}$ & \\
Heat 48 C. & 0.0255 & - \\
C -1 & 0.0177 & - \\
C -2 & 0.0209 & - \\
R-1 & 0.0185 & $-*$ \\
R-2 & 0.0200 & -3 \\
R -4 & 0.0212 & $-*$ \\
\hline
\end{tabular}

* Torso dripping wet.

M.H., Female, June 26, 1941. Cup on right arm. Heat applied to left arm. Room temperature $27.3-27.5^{\circ} \mathrm{C}$.

\begin{tabular}{c|c|c|c}
\hline & & \multicolumn{2}{|c}{ Silver nitrate test } \\
\cline { 2 - 4 } Period & Perspiration & Right arm & Left arm \\
\hline & $\begin{array}{c}\text { grams per 120 } \\
\text { sq. mm. per 10 } \\
\text { minutes } \\
\text { Heat 48 }\end{array}$ & & \\
C-1 & 0.0313 & - & - \\
C-2 & 0.0276 & - & - \\
L-1 & 0.0279 & - & - \\
L-2 & 0.0274 & - & + \\
L-3 & 0.0268 & - & ++ \\
L-4 & 0.0292 & - & $++^{*}$ \\
L-5 & 0.0283 & - & $++^{*}$ \\
L-6 & 0.0293 & \pm & + \\
\hline
\end{tabular}

* Torso dripping wet. 
respond to heat applied to a remote area having normal sensory innervation. Dry heat by means of the electric heater was applied to an arm of M. H., the patient referred to in procedure 4 above with cervical and lumbar sympathectomy. This operation, as described above, would prevent sympathetic impulses from reaching the areas to be studied. Likewise the heated region lacked sympathetic innervation, but the sensory nerves were intact. After a latent period profuse sweating appeared on the torso to which the sympathetic nerve supply was intact, but there was no significant increase in the amount of moisture obtained from the forehead or unheated arm to both of which the sympathetic nerves had been severed. These results are shown in Table II.

(6) An attempt to stimulate the sweat glands from a remote area lacking heat sensation. It appeared from the preceding experiment that sweat glands deprived of their sympathetic nerve supply would not secrete in response to heat applied to a distant region (the arm) possessing normal intact sensory innervation. The heat applied was sufficient to cause remote sweating in normal areas. The experiment to be described below was to discover whether sweat glands with an intact sympathetic nerve supply would respond to heat applied to another region, the sensory nerves of which had been destroyed. The patient M. L. had absence of pain and temperature sensation on his right side following an injury. On the application of dry heat to the anesthetic right arm, by the method described above, the silver nitrate test applied to the forehead showed a positive reaction and an essentially normal quantitative sweat response was produced on this remote part of the body (Table III). (Compare with normals in Table I.) Such significant increases in the amount of sweating from the forehead were always obtained in repeated experiments and, in addition, gross sweating. was usually seen on the face, torso and legs.

(7) An attempt to stimulate the sweat glands in a remote area by heating an anesthetized extremity. The experiment just described had significance only if there was complete absence of sensory nerves from the heated extremity. Consequently, it was thought wise to duplicate it on another individual in whom the interruption of
TABLE III

Lack of sensation on right side

M.L., Male, July 21, 1941. Cup on forehead. Room temperature 25.2-25.5 $\mathrm{C}$.

\begin{tabular}{|c|c|c|c|c|c|}
\hline \multicolumn{3}{|c|}{ Heat normal left arm } & \multicolumn{3}{|c|}{ Heat diseased right arm } \\
\hline Period & $\begin{array}{l}\text { Perspi- } \\
\text { ration }\end{array}$ & $\begin{array}{c}\text { Silver } \\
\text { nitrate } \\
\text { test } \\
\text { (Fore- } \\
\text { head) }\end{array}$ & Period & $\begin{array}{l}\text { Perspi- } \\
\text { ration }\end{array}$ & $\begin{array}{c}\text { Silver } \\
\text { nitrate } \\
\text { test } \\
\text { (Fore- } \\
\text { head) }\end{array}$ \\
\hline $\begin{array}{c}\text { Heat } 48^{\circ} \mathrm{C} \text {. } \\
C-1 \\
C=2 \\
L=1 \\
L=2 \\
L=3 \\
L=4\end{array}$ & $\begin{array}{c}\text { grams per } \\
120 \text { sq. mm. } \\
\text { per } 10 \text {. } \\
\text { minutes } \\
0.0176 \\
0.0153 \\
0.0145 \\
0.0149 \\
0.0223 \\
0.0341\end{array}$ & $\begin{array}{r}\bar{z} \\
++\dot{+} \\
+++t\end{array}$ & $\begin{array}{l}C_{1}-1 \\
C_{1}=2 \\
R=1 \\
R=2 \\
R=3 \\
R=4\end{array}$ & $\begin{array}{c}\text { grams per } \\
\text { 180 sq. mm. } \\
\text { per } 10 \\
\text { minutes } \\
0.0199 \\
0.0179 \\
0.0174 \\
0.0236 \\
0.0470 \\
0.0267\end{array}$ & 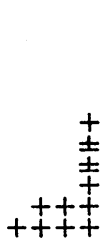 \\
\hline
\end{tabular}

M.L., Male, June 20, 1941. Cup on forehead. Room temperature 23.2-25.5 $\mathrm{C}$.

\begin{tabular}{|c|c|c|c|c|c|}
\hline \multicolumn{3}{|c|}{ Heat diseased right arm } & \multicolumn{3}{|c|}{ Heat normal left arm } \\
\hline Period & $\begin{array}{l}\text { Perspi- } \\
\text { ration }\end{array}$ & $\begin{array}{c}\text { Silver } \\
\text { nitrate } \\
\text { test } \\
\text { (Fore- } \\
\text { head) }\end{array}$ & Period & $\begin{array}{l}\text { Perspi- } \\
\text { ration }\end{array}$ & $\begin{array}{l}\text { Silver } \\
\text { nitrate } \\
\text { test } \\
\text { (Fore- } \\
\text { head) }\end{array}$ \\
\hline $\begin{array}{c}\text { Heat } 48^{\circ} \mathrm{C} \text {. } \\
\mathrm{C}=1 \\
\mathrm{C}=2 \\
\mathrm{R}=1 \\
\mathrm{R}=2 \\
\mathrm{R}=3 \\
\mathrm{R}=4\end{array}$ & $\begin{array}{c}\text { grams per } \\
\text { 180 sq. mm. } \\
\text { per } 10 \\
\text { minutes } \\
0.0209 \\
0.0226 \\
0.0377 \\
0.0426 \\
0.0530 \\
0.0571\end{array}$ & $\begin{array}{r}t \\
+t \\
+t+t \\
++t\end{array}$ & $\begin{array}{l}C_{1}-1 \\
C_{1}=2 \\
L=1 \\
L=2 \\
L=3 \\
L=4\end{array}$ & $\begin{array}{c}\text { grams per } \\
180 \text { se. mm. } \\
\text { per } 10 \\
\text { minutes } \\
0.0412 \\
0.0424 \\
0.0522 \\
0.0621 \\
0.0730\end{array}$ & $\begin{array}{r}++ \\
++ \\
+++\end{array}$ \\
\hline
\end{tabular}

the sensory nerves from the heated extremity was certain. The patient (M. A.) was a colored woman, probably suffering from Raynaud's disease but who had been free from symptoms for a year although she had received no treatment during that time. A brachial plexus block was established on the left side $^{2}$ : miosis, ptosis and enophthalmos of the left eye were present, but there was no anhydrosis. No sensation whatsoever was present in the left arm during the course of the experiment. Heating the anesthetized arm resulted in copious sweating on the forehead, a response greater than the control period before the block was performed (Table IV). The heated arm appeared perfectly dry and no evidence of sweat gland activity could be detected by the silver nitrate test.

\footnotetext{
2 We wish to thank Dr. Paul Searles, Professor of Anesthesia, University of Buffalo, for this difficult and expert technique.
} 
TABLE IV

Left brachial plexus blocked

M.A., Female, August 11, 1941. Cup on right side of forehead. Room temperature $22.6-23.8^{\circ} \mathrm{C}$.

\begin{tabular}{|c|c|c|c|c|c|}
\hline \multicolumn{6}{|c|}{ Heat left arm } \\
\hline \multicolumn{3}{|c|}{ Normal response } & \multicolumn{3}{|c|}{ After block of left brachial plexus } \\
\hline Period & $\begin{array}{l}\text { Perspi- } \\
\text { ration }\end{array}$ & $\begin{array}{c}\text { (Forehead) } \\
\text { AgNOz test }\end{array}$ & Period & $\begin{array}{l}\text { Perspi- } \\
\text { ration }\end{array}$ & $\begin{array}{l}\text { (Forehead) } \\
\text { AgNO; test }\end{array}$ \\
\hline $\begin{array}{l}C-1 \\
C-2 \\
L-1 \\
L-2 \\
L-3 \\
L-4\end{array}$ & $\begin{array}{l}0.0188 \\
0.0173 \\
0.0221 \\
0.0258 \\
0.0359 \\
0.0385\end{array}$ & $\begin{array}{c}\overline{-} \\
+ \\
++ \\
++ \\
++\end{array}$ & $\begin{array}{l}\mathrm{C}_{1}-1 \\
\mathrm{C}_{1}-2 \\
\mathrm{~L}_{1}-1 \\
\mathrm{~L}_{1}-2 \\
\mathrm{~L}_{1}-3 \\
\mathrm{~L}_{1}-4\end{array}$ & $\begin{array}{l}0.0210 \\
0.0308 \\
0.0547 \\
0.0570 \\
0.0686\end{array}$ & $\begin{array}{c}- \\
++ \\
+++ \\
\text { Gross sweat- } \\
\text { ing visible } \\
(-) \\
\text { Left arm }\end{array}$ \\
\hline
\end{tabular}

\section{DISCUSSION}

It is well known that following sympathectomy apparent anhydrosis of the region affected commonly occurs (12). Heating a normal extremity for sufficient length of time and with sufficient intensity to cause general sweating in a normal person failed to produce a quantitative increase in moisture output in remote sympathectomized regions in the experiments described. Thus it appears that the sympathetic innervation to the sweat glands or the motor side of the reflex arc must be intact to obtain a normal sweat response to heat applied to a remote region. That the sweat glands themselves are not at fault is well shown by their response to intracutaneous injections of mecholyl and to excessive local heat stimulation in areas to which the sympathetic nerves have been severed. Lewis and Landis (13) have similarly demonstrated that sweating can be provoked by pilocarpine. That the response of the sweat glands in sympathectomized areas to mecholyl and heat is not dependent on any nervous mechanism is strongly supported by the work of Bickford (14) who was unable to obtain any sweating response to a faradic stimulus in an arm sympathectomized two years previously. Additional evidence that the glands themselves are normal is afforded by histological study.

The normal or excessive response of the sweat glands in remote areas to heat applied to a region deprived of its sensory nerve supply indicates that the sensory side of the reflex arc is unnecessary for a normal sweating response. This was well shown in two individuals (M. L. and M. A.). This suggests that the heated blood acts directly on the central nervous system and results in a generalized sweating response except where sympathetic fibers supplying some particular area have been severed. Our subject M. A. showed a greater sweating response on the forehead on application of heat to the arm following anesthesia of the brachial plexus than in the control period. A possible explanation for this increase might be the vasodilatation of the arm vessels due to paralysis of the vasomotor fibers, with a greater amount of blood consequently exposed to the heat than during the control period. Thus more heated blood was carried to the central nervous system with a greater sweating response. However, some hormonal effect as the cause of sweating cannot be ruled out. That local stimulation of the sweat glands by the heated blood did not occur is shown by the negative silver nitrate test on the treated arm.

The failure of dry heat, when applied to the anesthetized arm, to cause activity of the sweat glands on the heated arm in this patient is in direct contrast to the activity of the sweat glands obtained in M. H. (Table II, Experiment II). A possible explanation for this contradiction is that in the patient with the brachial plexus block the sweat glands have not yet become sensitized, the block being performed just prior to the heating; whereas in the patient $M$. H., the sympathectomy was performed one year previously. Such sensitization is a common phenomenon in all tissues innervated by the sympathetic nervous system.

\section{CONCLUSIONS}

No histological change can be seen in sweat glands deprived of their sympathetic nerve supply.

The sweat glands themselves, in spite of severance of their sympathetic nerve supply, are still able to respond to intracutaneous injections of mecholyl and excessive local stimulation by heat.

In a human being the sympathetic fibers, or motor side of the reflex arc, must be intact for a normal sweating response to occur in a region remote from the heated area.

In spite of the absence of sensation in a heated region, a normal sweat response can still occur on other areas. The sensory side of the reflex arc is 
consequently unnecessary for a normal sweating response to occur following the application of heat. This suggests that heated blood acting on the central nervous system is the cause of generalized sweating. Whether the heated blood acts directly on the so-called heat centers or by liberating some hormone which in turn stimulates the centers is still uncertain.

The authors wish to express their gratitude to Dr. Fred R. Griffith, Jr., Professor of Physiology, who made many helpful suggestions in the carrying out of this work. We also wish to thank Dr. J. S. Regan and Dr. Gilbert Beck who furnished us the patients for study. The Department of Physiotherapy of the Buffalo General Hospital was very helpful in the loan of some of its apparatus and assistance in general.

\section{BIBLIOGRAPHY}

1. Dubois, E. F., Basal Metabolism in Health and Disease. Lea and Febiger, Philadelphia, 1936, p. 445.

2. Kuno, Y., The Physiology of Human Perspiration. Churchill, Ltd., London, 1934, p. 129.

3. Crew, W. H., and Whittle, C. H., On the absorption of ultra-violet radiation by human sweat. J. Physiol., 1938, 93, 335.
4. List, C. F., and Peet, M. M., Sweat secretion in man. Arch. Neur. and Psychiat., 1938, 40, 269.

5. Kuno, Y., The Physiology of Human Perspiration. Churchill, Ltd., London, 1934, p. 205.

6. Martin, C. J., Thermal adjustments of man and animals to external conditions. Lancet, 1930, 2, 673.

7. Best, C. H., and Taylor, N. B., Physiological Basis of Medical Practice. Williams and Wilkins, Baltimore, 1939, p. 1007.

8. Martin, C. J., Thermal adjustments of man and animals to external conditions. Lancet, 1930, 2, 561.

9. Cushing, H., Papers relating to the pituitary body, hypothalamus and parasympathic nervous system. Charles C. Thomas, Springfield, Ill., 1932, p. 55.

10. Aubert, Lyon Medical, 1874. Cited by Luciani, L., Human Physiology. MacMillan and Co., Ltd., London, 1913, p. 487.

11. Kuno, Y., The Physiology of Human Perspiration. Churchill, Ltd., London, 1934, p. 130.

12. Guttmann, L., The distribution of disturbances of sweat secretion after extirpation of certain sympathetic cervical ganglia in man. J. Anat., 1940, 74, 537.

13. Lewis, T., and Landis, E. M., Some physiological effects of sympathetic ganglionectomy in the human being and its effect in a case of Raynaud's malady. Heart, 1930, 15, 151.

14. Bickford, R. G., The mechanism of local sweating in response to faradism. Clin. Sc., 1938, 3, 337. 